\title{
Optimising economic and environmental performances of sheep-meat farms does not fully fit with the meat industry demands
}

\author{
Marc Benoit $^{1}$ (D) $\cdot$ Rodolphe Sabatier $^{2} \cdot$ Jacques Lasseur $^{3} \cdot$ Philip Creighton $^{4} \cdot$ Bertrand Dumont $^{1}$
}

Accepted: 4 July 2019 / Published online: 31 July 2019

(C) INRA and Springer-Verlag France SAS, part of Springer Nature 2019

\begin{abstract}
Ruminant farming systems are questioned for their contribution to climate change and feed-food competition. Here, we analyse the economic and environmental performances of five sheep farming systems optimised in terms of ewe productivity and feeding costs. Systems are located in contrasting biogeographical areas along a gradient of decreasing agronomic potential from Ireland to the French Mediterranean rangelands. Applying a mechanistic model of flock and farm operation management to evaluate these five systems made it possible to highlight trade-offs between their economic performance under standardised economic conditions, environmental performances, and feed-food competition, but also discrepancies between sheep farm strategy and meat industry demands. Different management strategies resulted in ewe productivity ranging from 0.82 to 1.66 lambs ewe $^{-1}$ year $^{-1}$ between farming systems and concentrate use from 0 to $148 \mathrm{~kg} \mathrm{ewe}^{-1}$ year $^{-1}$. The two systems relying the most on grassland and rangelands show the best economic and environmental performances while minimising feed-food competition. This results from a good match between animal feed requirements and forage availability; these systems, however, generate a high seasonality of production that does not meet the industry demand for a regular meat supply throughout the year. The Irish system also follows a forage autonomy strategy, but with poorer environmental and economic performance due to intensification, higher price of land, and lower meat price. Both the accelerated reproduction system with three lambing periods in two years and the organic system generate a more regular lamb supply, but require a higher level of concentrate feed, which negatively affects performances. These results highlight for the first time that optimising economic and environmental performances at farm level does not fully fit with the meat industry demand for a regular lamb meat supply throughout the year and lamb conformation. Low-productivity but fully self-sufficient fodder livestock systems can achieve excellent economic performance, but require both specific skills and marketing adequacy.
\end{abstract}

Keywords Ruminants $\cdot$ Farming system $\cdot$ Feed-food competition $\cdot$ Modelling $\cdot$ Trade-offs $\cdot$ Agroecology $\cdot$ Organic farming . Pastoralism

Marc Benoit

marc-p.benoit@inra.fr

1 Université Clermont Auvergne, INRA, VetAgro Sup, UMR Herbivores, F-63122 Saint-Genès-Champanelle, France

2 INRA UR 767 Ecodeveloppement, F-84000 Avignon, France

3 INRA UMR Selmet, F-34000 Montpellier, France

4 Teagasc, Mellows Campus, Athenry, Co. Galway H65 R718, Ireland

\section{Introduction}

European sheep farming has faced several difficult decades despite support for production via European subsidies. This is the result of a conjunction of three factors (European Parliament 2008; Rossi 2017): (i) cheap sheep-meat imports from Australia and New Zealand put strong competitive pressure on local production systems during the 1990s and early 2000s, (ii) sheep farming is labour intensive and among the less remunerative agricultural activities, which often discouraged sheep farming, (iii) the Common Agricultural Policy 
(CAP) largely focussed on cropping systems from 1992 to 2010. From 2010, two processes combined in offsetting pressure on low sheep-meat prices: (i) the drop in European production that was initiated by the 2001 foot-and-mouth disease crisis in Great Britain and (ii) a decline in sheep production in New Zealand. As a consequence, sheep-meat prices have been relatively high and stable since 2010 in Europe. However, the production is still declining in most European countries (OECD 2015). Indeed, the profitability of sheep farms can remain low because of high production costs, mainly associated with animal feeding. Sheep farmer's working conditions are moreover still considered to be demanding.

A specificity of sheep farming is the wide diversity of production systems (Ripoll-Bosch et al. 2014; O'Rourke et al. 2016). Given ewe reproductive specificities (short gestation period, prolificacy from 100 to $250 \%$ according to breed) and with accelerated breeding programmes, ewe productivity was shown to vary from 0.50 to 2.50 lambs per ewe per year across French sheep-meat farms (Benoit and Laignel 2011), which corresponds to a potential production of 8 to $50 \mathrm{~kg}$ of lamb carcass. In addition, feeding strategies are extremely variable, ranging from a large amount of concentrates used to situations where only forage resources are used. The wide range of ewe productivity and concentrate consumption levels make these two variables key drivers of economic and environmental performance as greenhouse gas (GHG) emissions and non-renewable energy consumption (Benoit and Laignel 2011). Sheep production is present across a very wide range of bioclimatic and grazing land conditions in Europe, from productive lowland areas to dry pastoral areas in Mediterranean regions (Rossi 2017). A number of sheep breeds have proven to be very well adapted to this diversity of production and environmental conditions.

Livestock production is often blamed for its role in global warming and for its relative inefficient protein conversion into animal products. When partly fed on cereal crops, herbivores also compete with human food from arable lands. However, when fed on grasslands and with by-products from human food that are inedible by humans, herbivores have a high efficiency of conversion to human-edible proteins (Ertl et al. 2015). Beyond production, herbivore farming systems also provide a wide range of services including regulatory and cultural services, so-called bundles of services vary according to livestock management, with a key effect of stocking density and proportion of forages in the diet (Dumont et al. 2019). Ecosystem services are assumed to be both enhanced and valued in agroecological livestock production systems (Dumont et al. 2018), in particular those making the best use of local resources.

In this article, we compare the technical, economic, and environmental performance of five contrasting sheep farming systems. Each of them are optimised for forage autonomy according to local environmental conditions. Our hypothesis is that under highly contrasting conditions from an agronomic point of view, there is variability in management conditions that optimise farm multi-performance (Fig. 1). Applying a modelling framework to the evaluation of these five systems made it possible to highlight (i) relationships between resource characteristics and farmers' strategy, (ii) the specificities and multi-performance of these contrasting farming systems, and (iii) trade-offs between economic and environmental performances, but also discrepancies between sheep farm performance and meat industry demands.

\section{Materials and methods}

\subsection{Choice of five efficient farms}

A preliminary analysis of a database of 1462 farm years (Benoit and Laignel 2011) based on 118 farms, each surveyed on average over 12 years, shows the high variability of two key economic indicators: ewe productivity and concentrate feed requirements. These two variables are good proxies for farm efficiency. Indeed, concentrate feed is the main production cost for sheep farming, representing on average $64 \%$ of the operational costs in this group of farms. Ewe productivity is the most correlated indicator to gross margin per ewe, which is the most correlated indicator to farm net income (Benoit and Laignel 2011). This leads us to consider that the ratio
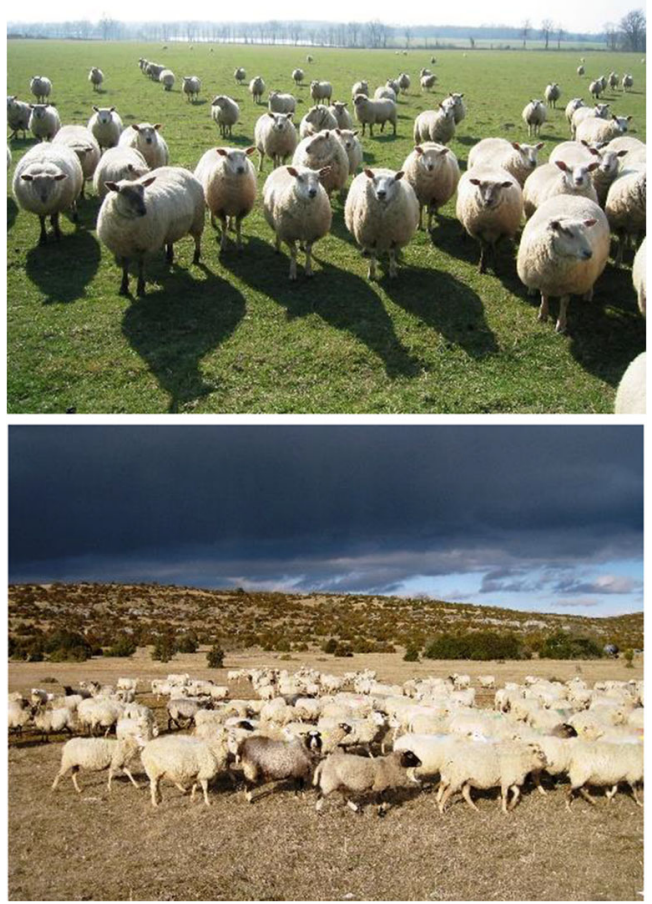

Fig. 1 Various forage-based strategies and sheep breeds to adapt to the diversity of local context in search of high performances. Pictures represent lowland and upland areas. (Pictures M.Benoit) 
[Quantity of concentrates per ewe]/[Ewe productivity] is a key determinant of flock efficiency from a technical and economic point of view. Figure 2 illustrates the wide variability of concentrate feed use among farms. It also shows the balance between the two key criteria across the whole network of 118 farms distributed in either uplands or lowlands.

Among the 118 farms, we selected the five farms in which the lowest amount of concentrate feed was needed for a given ewe productivity level, that is to say the farms with a very high level of fodder self-sufficiency, along various levels of ewe productivity. For example, according to Fig. 2, the farms represented by stars called $O F$ and Graz have a numerical productivity of approximately $150 \%$ and a concentrate feed consumption of $85 \mathrm{~kg}$ and $48 \mathrm{~kg}$ per ewe per year, respectively. They thus outperform other farms from the same areas experiencing the same level of ewe productivity but with a concentrate feed consumption around $150 \mathrm{~kg}$ per ewe per year.

We notice that the five farms are located on a gradient of decreasing agronomic potential, from Ireland (Irel: humid oceanic conditions) to four French production areas: the western lowlands (Graz, grazing farm), the Massif central uplands (accelerated reproduction system with three lambings every 2 years $3 \times 2$, and organic farming $O F$ ), and the Mediterranean rangelands (very mobile, dual transhumant, $D T$ ). Three farms (3x2, Graz, OF) came from the previous database (Benoit and Laignel 2011); the two others (DT) (Vigan et al. 2017) and Irel (Earle et al. 2017) were selected in order to extend the biogeographical conditions and to better match the reality of European forage-based sheep production systems. In both uplands and lowlands, there are disparities between farms (Benoit and Laignel 2011) (Fig. 2), but our goal was to assess the multi-performance of farms adapted to their biophysical environment rather than to describe sheep-meat farm performance within and across areas. The pedoclimatic conditions

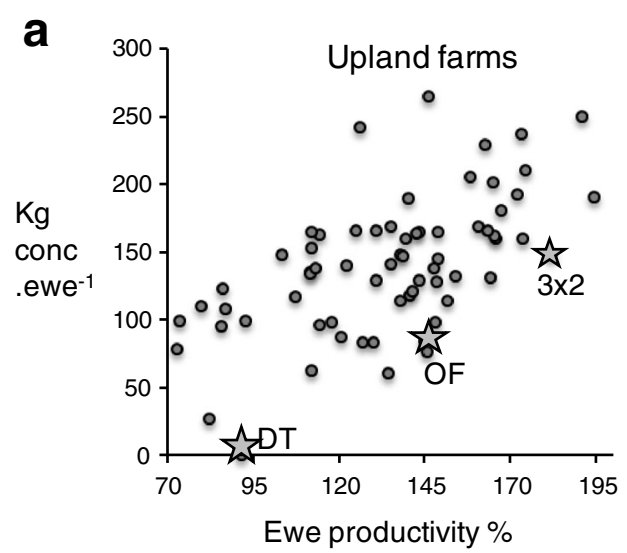

Fig. 2 Position of 118 sheep farms (one point representing on average 12year monitoring) for concentrate feed requirements per ewe per year relative to ewe annual productivity, i.e. a proxy of concentrate feed use efficiency. The five farms studied are represented by stars. On the left (a): farms in North Massif Central, with $O F$ for Organic Farming and $3 \times 2$ for of the five farms studied do not differ from those of the other farms in their region. Table 1 summarises the pedoclimatic context of the five farms, the assets and constraints they face, and farmer management strategies. The analysis was conducted over 3 to 5 years in order to buffer variability in animal reproduction performance and climatic hazards.

\subsection{Choice of performance indicators}

We selected 23 variables to describe farm structure, flock management and technical performance, farm economic and environmental performance, and feed-food competition. These indicators, presented in Table 2, allow ten key indicators for assessing farm multi-performance to be calculated.

A first set of three indicators relates to technical performance: ewe productivity, consumption of concentrates, and feed self-sufficiency. Ewe productivity and consumption of concentrates are indeed major determinants of sheep farm profitability (Benoit and Laignel 2011; Bellet and Ferrand 2014), while feed self-sufficiency is a direct indicator of farm autonomy. Feed self-sufficiency was calculated as the share of the flock energy requirements met from farm resources (fodder and crops) (Benoit and Laignel 2006). As none of the farms produced crops that were used to feed the animals, feed self-sufficiency highly depended on the efficiency of forage utilisation and on the quantity of concentrate feed offered per ewe and per year.

Three economic indicators were calculated. We assessed farm profitability from added value per total worker that is derived from the net income, i.e. gross product minus total production costs. We opted for added value as it does not account for subsidies, nor for wages and social costs, taxes, amortisation, and financial expenses. Added value thus reveals the ability of the farm to produce sheep-meat with the

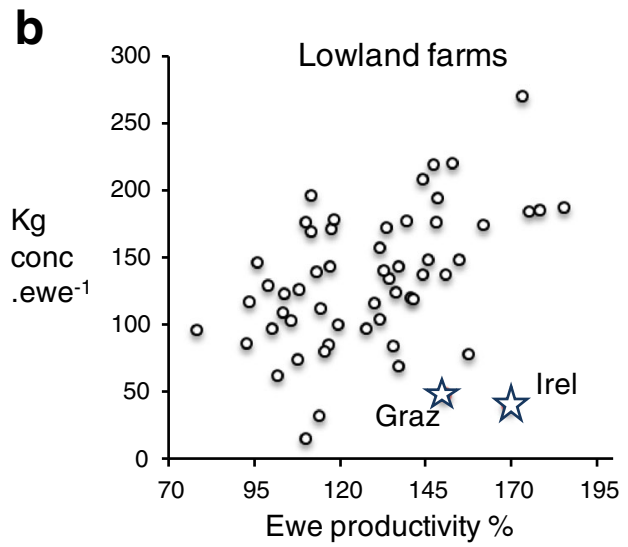

accelerated reproduction system, and rangeland farm in Provence with $D T$ for Dual Transhumant system. On the right (b): pasture based farms from lowlands, in France South Vienne with Graz for Grazing system and in Ireland with Irel system 
Table 1 Context of the five farms studied, assets and constraints, strategies implemented to optimise farm performances, and consequences on lamb selling. Systems are ranked from lowland (Irel for Irish system and Graz for Grazing system) to upland areas (3x2 for accelerated reproduction system and $O F$ for Organic Farming) and pastoral Mediterranean conditions (DT for Dual Transhumant farming system)

\begin{tabular}{|c|c|c|c|c|c|}
\hline Farms & Irel & Graz & $3 \times 2$ & $O F$ & $D T$ \\
\hline $\begin{array}{l}\text { Pedo-climatic } \\
\text { context }\end{array}$ & Oceanic climate & $\begin{array}{l}\text { Unfavorised lowlands } \\
\text { Continental climate } \\
\text { Short winter } \\
\text { Dry summer }\end{array}$ & $\begin{array}{l}\text { Massif central uplands } \\
\text { Continental climate } \\
\text { Altitude } 800 \mathrm{~m} \\
\text { Volcanic soil }\end{array}$ & $\begin{array}{l}\text { Massif central uplands } \\
\text { Continental climate } \\
\text { Altitude } 800 \mathrm{~m} \\
\text { Granitic soil }\end{array}$ & $\begin{array}{l}\text { Mountain and pastoral } \\
\text { areas in Alpine pastures, } \\
\text { Provence hills and } \\
\text { lowlands Mediterranean } \\
\text { and Alpine climate }\end{array}$ \\
\hline $\begin{array}{l}\text { Farming } \\
\text { system }\end{array}$ & $\begin{array}{l}\text { Intensive use of } \\
\text { pastures in a } \\
\text { farmlet experiment }\end{array}$ & Grassland-based & $\begin{array}{l}\text { Intensive reproduction } \\
\text { ( } 3 \text { lambings every } \\
2 \text { years })\end{array}$ & $\begin{array}{l}\text { Grassland-based } \\
\text { organic system }\end{array}$ & $\begin{array}{l}\text { Traditional dual } \\
\text { transhumance (Royer } \\
\text { 1988). Very low } \\
\text { stocking rate. } \\
\text { Harsh conditions. } \\
\text { Very low inputs use }\end{array}$ \\
\hline Ref. years & 2013-2014-2015 & 1992-1993-1994 & 2004-2005-2006-2007 & 2014-2015-2016 & 2013-2014-2015 \\
\hline Strengths & $\begin{array}{l}\text { Favourable area } \\
\text { (oceanic climate) } \\
\text { with regular } \\
\text { grass growth. }\end{array}$ & $\begin{array}{l}\text { Ploughable area } \\
\text { (temporary } \\
\text { pastures) } \\
\text { Cheap land renting }\end{array}$ & $\begin{array}{l}\text { Fertile soils. High } \\
\text { quality forages for } \\
\text { stocks (silage) } \\
\text { High lamb price } \\
\text { in winter }\end{array}$ & $\begin{array}{l}\text { Higher price of } \\
\quad \text { organic lamb meat }\end{array}$ & $\begin{array}{l}\text { Large range of altitude } \\
\text { ( } 0 \text { to } 2500 \mathrm{~m} \text { asl) } \\
\text { Marketing to Muslims } \\
\text { (6-15 months badly } \\
\text { conformed lambs). }\end{array}$ \\
\hline Constraints & $\begin{array}{l}\text { Expensive price } \\
\text { of land. }\end{array}$ & Summer drought & $\begin{array}{l}\text { Six months indoor. } \\
\text { Few land available. }\end{array}$ & $\begin{array}{r}\text { Low grassland } \\
\text { productivity }\end{array}$ & $\begin{array}{l}\text { Very low rangeland } \\
\text { productivity and } \\
\text { stocking rate. } \\
\text { Wolf predation. }\end{array}$ \\
\hline Solution & $\begin{array}{l}\text { One lambing (end of } \\
\text { winter) Grass } \\
\text { fattened lambs with } \\
\text { high meat production } \\
\text { per ha and ewe } \\
\text { productivity. High } \mathrm{N} \\
\text { fertilisation and low } \\
\text { forage stocks. } \\
\text { Belclare breed. }\end{array}$ & $\begin{array}{l}\text { One lambing (end } \\
\text { winter). Grass } \\
\text { fattened lambs. } \\
\text { No } \mathrm{N} \text { fertilisation. } \\
\text { All year grazing. } \\
\text { Mouton Vendéen } \\
\text { and Texel breeds. }\end{array}$ & $\begin{array}{l}\text { High ewe productivity } \\
\text { (accelerated } \\
\text { reproduction without } \\
\text { hormones use) } \\
\text { Concentrate fattened } \\
\text { lambs Productive and } \\
\text { rustic breed (Rava) } \\
\text { crossed with } \\
\text { "meat breed". }\end{array}$ & $\begin{array}{l}\text { Reproduction: } 2 / 3 \\
\text { spring lambings } \\
\text { (lambs fattened on } \\
\text { grass); } 1 / 3 \text { autumn } \\
\text { lambongs Full year } \\
\text { grazing for a part of } \\
\text { the flock. } \\
\text { Optimisation of } \\
\text { forage used. } \\
\text { Limousine breed. }\end{array}$ & $\begin{array}{l}\text { Two lambing periods } \\
\text { (March -October). } \\
\text { Large pastoral areas, } \\
\text { with } 500 \text { ha of } \\
\text { vineyards in winter. } \\
6 \text { weeks spring } \\
\text { transhumance }(200 \mathrm{~km}) \text {. } \\
\text { No buildings nor stocks. } \\
\text { Rustic, low prolificacy } \\
\text { breed, Mourerous }\end{array}$ \\
\hline Lamb selling & $\begin{array}{l}\text { Seasonal: July to } \\
\text { October }\end{array}$ & $\begin{array}{l}\text { Seasonal: mainly } \\
\text { July to November }\end{array}$ & $\begin{array}{l}\text { Nearly all the year } \\
\text { round }\end{array}$ & $\begin{array}{l}\text { From February to } \\
\text { November }\end{array}$ & $\begin{array}{l}\text { Seasonal: August to } \\
\text { November for males. } \\
\text { Early selling for female }\end{array}$ \\
\hline
\end{tabular}

minimum of physical inputs (in particular concentrate feed, fertilisers, fuel), and so with the maximum utilisation of onfarm resources. In order to understand the drivers of farm profitability, we calculated two other widely used indicators (Benoit and Laignel 2011; Ripoll-Bosch et al. 2014): Gross margin per ewe reveals ewe production level reached with a minimum of inputs and structural cost per Equivalent Livestock unit acounts for mechanisation costs, housing facilities, management, financial, and wage costs. As stocking rate could be very different across farms, we did not compare structural cost per ha, and rather calculated it per Equivalent Livestock Unit, defined as the sum of Livestock Unit and ha of arable land (Benoit and Laignel 2006). This can be done as structural costs per ha are similar between arable and fodder areas in our database of 1462 farm years, with a stocking rate averaging $1 \mathrm{LU} \mathrm{ha}^{-1}$. All these economic indicators are calculated for a full production year.
Feed-food competition was assessed by an indicator that accounts for ewe and lamb feeding resources with regard to the use of human-edible resources (Wilkinson 2011; Ertl et al. 2015; Mottet et al. 2017). We used the Efficiency of Conversion of Edible Proteins by Human (ECCPH) defined as [Proteins supplied (meat, offal) consumable by humans/proteins consumed by the animals which were also human-edible] $\times 100$.

Farm environmental impacts are assessed through three key indicators: GHG emissions, non-renewable energy consumption, and $\mathrm{N}$ balance at the farm scale. Contribution to global warming is assessed through GHG emissions calculated as gross emissions minus carbon sequestration in the soil. Carbon sequestration in grasslands was calculated from Dollé et al. (2013). Greenhouse gas emissions and non-renewable energy (NRE) consumption are expressed per $\mathrm{kg}$ of carcass produced after allocation of the share of GHG or NRE corresponding to wool production, on a protein content basis. Greenhouse gas emissions 
Table 2 Characteristics of the five farms (Structure, flock size), technical performances for reproduction, concentrate use and type of lambs, and economic, environmental, and feed-food competition indicators. Figures in italic characters correspond to the indicators selected for farm selection (Fig. 2) and indicators discussed. Irel for the Irish system, Graz for Grazing, $3 \times 2$ for accelerated reproduction system, $O F$ for Organic Farming, and $D T$ for Dual Transhumant system

\begin{tabular}{|c|c|c|c|c|c|}
\hline Farms & Irel & Graz & $3 \times 2$ & $O F$ & $D T$ \\
\hline \multicolumn{6}{|l|}{ Structure } \\
\hline Total agricultural area (ha) & 36.8 & 81.9 & 53.9 & 91.9 & 4463 \\
\hline Stocking rate (ewe/ha fodder area) & 11.4 & 6.6 & 8.7 & 4.4 & 0.5 \\
\hline No ewe (> 6 months) & 420 & 541 & 470 & 405 & 2105 \\
\hline Workers (UWH) & 1.00 & 1.50 & 1.50 & 1.00 & 4.67 \\
\hline Work productivity (eq.Livestock Unit $\mathrm{W}^{-1}$ ) & 66.3 & 54.6 & 46.0 & 59.7 & 72.5 \\
\hline \multicolumn{6}{|l|}{ Flock management, lambs, and feeding } \\
\hline Prolificacy $(\%)$ & 218 & 155 & 166 & 174 & 109 \\
\hline Ewe productivity (+ 6 months) $(\%)$ & 154 & 133 & 166 & 132 & 82 \\
\hline Ewe mortality $(\%)$ & 8.3 & 3.3 & 5.8 & 4.8 & 18.9 \\
\hline Lamb weight ( $\mathrm{kg}$ carc $\mathrm{hd}^{-1}$ ) & 19.9 & 20.0 & 16.3 & 17.0 & 16.6 \\
\hline Price of fattened lambs $\left(€ \mathrm{~kg} \mathrm{carc}^{-1}\right)$ & 4.76 & 6.43 & 6.64 & 7.03 & 7.82 \\
\hline Concentrates $\left(\mathrm{kg}\right.$ ewe +6 months $\left.^{-1}\right)$ & 36.5 & 42.2 & 134.6 & 77.1 & 0.0 \\
\hline Concentrates $\left(\mathrm{kg} \mathrm{carc}{ }^{-1}\right)$ & 1.22 & 1.55 & 5.24 & 3.41 & 0.00 \\
\hline Feed self-sufficiency (\%) & 94.9 & 94.3 & 78.2 & 88.1 & 100.0 \\
\hline \multicolumn{6}{|l|}{ Economic data and performance } \\
\hline Gross margin $\left(€\right.$ ewe $\left.^{-1}\right)$ & 89 & 132 & 121 & 115 & 74 \\
\hline Structural cost ( $€$ Equivalent Livestock Unit ${ }^{-1}$ ) & 555 & 533 & 642 & 794 & 483 \\
\hline Land rental $\left(€ \mathrm{~kg} \mathrm{carc}{ }^{-1}\right)$ & 1.08 & 0.50 & 0.61 & 1.03 & 1.91 \\
\hline $\begin{array}{l}\text { Added value }\left(€ \mathrm{~W}^{-1}\right) \text { (in French economic } \\
\text { situation for lamb price) }\end{array}$ & $21,400(40,500)$ & 31,700 & 19,800 & 22,500 & 31,900 \\
\hline \multicolumn{6}{|l|}{ Environmental performance } \\
\hline $\mathrm{N}$ balance $\left(\mathrm{Kg} \mathrm{N}\right.$ ha $\left.\mathrm{TAA}^{-1}\right)$ & 98 & -1 & 25 & 5 & -3 \\
\hline Gross GHG emissions (Eq CO $\mathrm{kg} \mathrm{carc}^{-1}$ ) & 21.7 & 18.3 & 22.5 & 24.8 & 28.6 \\
\hline $\mathrm{CH}_{4} /$ Gross $\mathrm{GHG}$ emissions $\left(\% \mathrm{EqCO}_{2}\right)$ & 50.1 & 75.7 & 58.4 & 72.6 & 79.3 \\
\hline Net $G H G$ emissions $\left(\mathrm{EqCO}_{2} \mathrm{~kg} \mathrm{carc}^{-1}\right)$ & 19.2 & 13.7 & 16.6 & 8.5 & -130.0 \\
\hline Total MJ non renew. energy (MJ kg $\operatorname{carc}^{-1}$ ) & 50.6 & 31.4 & 50.9 & 47.6 & 22.7 \\
\hline \multicolumn{6}{|l|}{ Feed/food performance } \\
\hline Effic. conversion of edible proteins (\%) & 158 & 125 & 33 & 51 & $\infty$ \\
\hline
\end{tabular}

and NRE values were calculated from the Life Cycle Assessment methodology used in the French Dia'Terre tool based on the Gestim model (Gac et al. 2011). Methane is the main component of GHG emissions; methane emissions by the animals were calculated from Vermorel et al. (2008) according to estimated daily intake of forages, concentrate feed, and animal metabolic weight. We also calculated nitrogen balance at farm scale according to the Economic Input:Output (EIO) budget, which accounts for purchases and sales of nitrogen over the farm gate without accounting for N symbiotic fixation (Watson and Atkinson 1999). Positive nitrogen balance reveals a risk for $\mathrm{N}$ leaching.

\subsection{Simulation tool to calculate indicator values}

A mechanistic model of flock and farm operation management (Ostral) was used to simulate the diversity of reproduction strategies that occur in sheep-meat production systems (seasonality, "acceleration" of reproduction), while accounting for the types of resources (various fodder types, crops used as concentrate feed and cash crops). Ostral was initially used to settle precisely flock functioning in terms of reproduction and to calculate flock indicators of performance such as ewe productivity (Benoit 1998). We used Ostral to simulate farm operations and to calculate the technical performance of each farm studied. Farm data (3-5 years) from case studies, combined with expert knowledge when needed, are used to describe feeding strategy (i.e., the quantity and type of concentrates and forages offered to each batch of sheep throughout the year according to animal feeding needs), crop and grassland fertilisation, crop yields, etc. According to the different farm characteristics and practices (quantity of each type of stored fodder, ha of crops, tons of manure to be spread, 
etc.) Ostral simulates the standard levels and type of equipment needed in order to calculate equipment depreciation. Indeed, equipment has a key impact on economic performance but also on environmental performances (indirect energy accounted for, in LCA). For the four French farms, we applied the same economic conditions for lamb and input prices (concentrates, fertilisers, fuel, etc.), i.e. those of the year 2015. Economic results of Irel are also based on the year 2015, but on the Irish context. Social contributions were calculated by Ostral as $28 \%$ of the net income for the five farms (France or Ireland). This rate comes from the analysis of the long-term network of farms used to choose the five farms (see above). It is lower than the official French rate $(42 \%)$ because the net income we calculated from a management perspective is higher than the net income calculated from a tax perspective.

Ultimately, the use of the Ostral simulator made it possible to calculate the indicators reported in Table 2, some of which are not directly available from farm surveys such as the environmental indicators (Vigan et al. 2017). These add to the classical technical and economic indicators (gross margin per ewe, net income, etc.) that are thus calculated from a consistent set of input and output variables. It is noteworthy that the Ostral simulator can also extrapolate farm performances according to flock size, which was used to simulate a 420-ewe commercial Irish farm from a farmlet experiment with 60 ewes. Finally, Ostral allows accounting for various types of technical and market hazards (animal fertility, prolificacy, mortality; economic value on energy, concentrates, meat) affecting farm technical and economic performance (Benoit and Laignel 2014).

Data availability The datasets generated during and/or analysed during the current study are available from the corresponding author on reasonable request.

\section{Results and discussion}

\subsection{Farm structure and technical performance}

Table 2 gives the main characteristics of the five farms in terms of structure with a huge variability in size and stocking rate. While the number of farm workers across flocks ranged from one to five (405 to 2105 ewes), productivity per worker only ranges from 46 to $72 \mathrm{LU} \mathrm{W}^{-1}$. Technical performance is quite different across farms. If we limit our analysis to key indicators that were previously discussed (ewe productivity and concentrate use) and considered as optimal combinations based on Fig. 2, we see a wide range of ewe annual productivity from $82 \%$ (DT farm) to $166 \%(3 \times 2)$ and of concentrate use from 0 to $134.6 \mathrm{~kg}$ concentrates per ewe per year. $D T$ is indeed penalised by a very high ewe mortality rate (19\%), nearly half of it being due to wolf predation in spite of prevention devices (Lasseur 2008).

\subsection{Economic performance}

\subsubsection{At the level of the sheep enterprise}

Gross margin is a core indicator explaining a large part of farm profitability in sheep-meat production systems. Graz gets the highest gross margin per ewe (132€), thanks to high ewe productivity, lamb weight and price (the highest gross product at $187 € /$ ewe), and very low feeding and fertiliser costs (Table 2). Systems $3 \times 2$ and $O F$ are not far behind (with $121 €$ and $115 €$ gross margin, respectively), thanks to high ewe productivity and lamb prices and in spite of the highest input levels in $3 \times 2$ (Table 2). Ewe productivity was lower in OF but this reduction was coupled with a strong decrease in concentrate use ($43 \%$ compared to $3 \times 2$ ) as a consequence of the high cost of organic concentrate feed (+39\% compared to conventional). Irel gets a $-33 \%$ gross margin per ewe compared to Graz (89€) because of the $27 \%$ lower lamb price in Ireland (4.76€ $\mathrm{carc}^{-1}$ carcass vs 6.43 for $\mathrm{Graz}$, for the same type of lambs and selling period). If the same lamb price was obtained as in the Graz farm, gross margin per ewe would be $2 \%$ higher than in Graz (135 vs $132 €$ ewe $^{-1}$ in Irel and Graz, respectively). Irel proportional costs are globally the same as in Graz. However, the management of the fertilisation is quite different: it is based on nitrogen for Irel, while no mineral $\mathrm{N}$ fertilisation was used in Graz. That is related with stocking rate which is nearly double for Irel (Table 2). DT gets a 44\% lower gross margin per ewe compared to Graz (74€), with a $38 \%$ lower ewe productivity. Sale price was good for male lambs but low for non-fattened females. Sheep operational costs were the lowest ( $-72 \%$ compared with Graz) due to very low inputs (i.e. no concentrate feed and only $0.5 €$ ewe $^{-1}$ for fertilisers).

\subsubsection{At farm level}

Beyond gross margin, structural costs account for mechanisation, housing facilities, management, financial and wage costs, etc. DT shows the lowest structural costs per Equivalent Livestock Unit (483€ per equivalent livestock unit, LU) and $O F$ the highest (794€). Indeed, $D T$ has very little equipment (due to no fodder stock) and buildings. Its main structural cost is social contribution ( $46 \%$ of total) that results from a high net income. Structural costs per LU is rather low for Graz and Irel (534€ and 555€ respectively) where the share of equipment is $35 \%$ and $38 \%$ respectively vs $24 \%$ for DT. The share of each of the components of the structural costs were very different across farms; land renting is the main cost 
for Irel, as the price of land is very expensive $\left(370 € \mathrm{ha}^{-1}\right)$ and represents $38 \%$ of the total structural costs, at $1.1 € \mathrm{~kg}$ carcass $^{-1}$ ( $23 \%$ of the lamb price). Land renting price is only $9.0 € \mathrm{ha}^{-1}$ for DT but, as both rangeland agronomic potential and ewe productivity are very low, it accounts for $1.9 € \mathrm{~kg}$ carcass $^{-1}$ (i.e. $24 \%$ of lamb price). $O F$ structural costs per equivalent livestock unit are the highest as (i) the low stocking rate leads to expensive land rental per ewe $\left(1.0 € \mathrm{~kg}_{\text {carcass }}{ }^{-1}\right)$, (ii) equipment and mechanisation are costly as a part of the flock is kept indoors from November to April with large forage stocks needed for winter feeding (as for $3 \times 2$ ), and (iii) social contributions are high, as net income is quite high.

Finally, added value is the most suitable indicator of farm economic performance to illustrate the farms ability to use local resources for producing meat. The highest added values are for DTand Graz (31,900 and 31,700€, respectively) which have a flock management driven by the search for maximum autonomy combined with a high animal productivity for Graz and a high work productivity for DT. Added values in $3 \times 2$ and $O F$ systems are significantly lower (19800 and 22500, respectively) as they show lower fodder self-sufficiency and/or a high price of inputs (concentrate, for $O F$ ). The Irel added value is comparable to that of $3 \times 2$ and $O F(21,400 €)$ but, under French economic conditions for lamb prices, it would be the highest, at 40,500€. Finally, the good economic performance of the five farms is confirmed by the comparison to French national references. According to the RICA (National Accounts Network for Agriculture) database, meat sheep farms with more than 250 ewes $(n=142)$ get a $2814 €$ added value per family worker. The lowest of the four French farming systems studied (3x2) is 19,800€, and this is despite our case study upland farm facing strong pedoclimatic constraints.

\subsection{Feed-food competition and environmental performance}

\subsubsection{Feed-food competition}

Because of high concentrate consumption in $3 \times 2$ farm, $10.1 \%$ of the total proteins consumed by ewes are human-edible, which is the highest value for all five farms, the lowest value being $0 \%$ for $D T$ in which sheep are feed on forages only (values between 8.1 and $9.1 \%$ for the three other farms). Protein conversion efficiency (protein production compared to total protein intake) is however low for DT (5.5\% vs between 8.3 and 10.1 for the four other farms) because of low ewe productivity and late male-lamb slaughtering (type of lambs requested by Muslim markets). Finally, as animals do not consume feed that are human-edible in $D T$, the conversion efficiency for protein consumable by humans $(\mathrm{ECCPH})$ is infinite. ECCPH is higher than $100 \%$ for Irel and Graz. ( $158 \%$ and $125 \%$, respectively), which reveals that meat produced from these three grass-based farming systems yields more human-edible proteins than they utilise, so that these systems are very interesting for food security.

\subsubsection{Nitrogen balance}

Three of the five farms get close to a zero $\mathrm{N}$ balance ( $\mathrm{Graz}$, $O F, D T)$ as there is no or very low $\mathrm{N}$ mineral fertilisation and no or very moderate use of concentrate feed (Table 2). Nitrogen surplus is $25 \mathrm{~kg} \mathrm{ha}^{-1}$ for $3 \times 2$, because of the amount of concentrate feeds. The Irish farm has the highest $\mathrm{N}$ surplus, at $98 \mathrm{~kg} \mathrm{~N}^{-1}$ because of a high $\mathrm{N}$ fertilisation application rate $\left(103 \mathrm{~kg} \mathrm{~N} \mathrm{ha}^{-1}\right)$. However, we can consider that the risk of $\mathrm{N}$ leaching is limited, as the agricultural area of the farm consists only of pastures and as nitrogen supply is fragmented along the grazing season.

\subsubsection{Greenhouse gas emissions}

When calculating gross GHG emissions per kg carcass, Graz appears as the most efficient farming system (Table 2) as it is the second most productive in term of meat produced per ewe (30.8 kg carcass ewe $\mathrm{kear}^{-1}$ ) with very low input levels, in particular no mineral $\mathrm{N}$ fertilisation (providing $\mathrm{N}_{2} \mathrm{O}$ emissions). Its $\mathrm{GHG}$ emissions are the lowest, at $18.3 \mathrm{Eq} \mathrm{CO}_{2} \mathrm{~kg}$ carc $^{-1}$. Irel and $3 \times 2$ are two productive farming systems with some inputs ( $\mathrm{N}$ fertiliser for Irel and concentrates for $3 \times 2$ ) and get 21.7 and $22.5 \mathrm{Eq} \mathrm{CO}_{2}$ carcass $\mathrm{kg}^{-1}$, respectively. OF is less productive and its production is partly based on concentrate feed; its gross GHG emissions is $24.8 \mathrm{Eq} \mathrm{CO}_{2} / \mathrm{kg}$ carcass. DT is based on nearly no concentrate feed, nor mineral fertilisation. As the ewe productivity is low and male lambs are sold late resulting in significantly higher $\mathrm{CH}_{4}$ emission over their lifetime, $\mathrm{CH}_{4}$ contribution is high when expressed per $\mathrm{kg}$ of carcass. It accounts for $79.3 \%$ of the total $\mathrm{GHG}$ emissions, whereas it only represents $50.1 \%$ of it for Irel. However, farm ranking is strongly modified when accounting for carbon sequestration in pastures and rangelands. Indeed, the less animal-intensive systems are also the less landintensive ones, with a low stocking rate and thus the highest carbon sequestration per $\mathrm{kg}$ carcass. Net GHG emissions are thus very low for $O F$ (8.5 Eq $\mathrm{CO}_{2} / \mathrm{kg}$ Carc) and negative (positive carbon balance) for $D T$, which highlights the importance of considering both GHG emissions and sequestration when evaluating the effect of a farming system on GHG.

\subsubsection{Non-renewable energy (NRE) consumption}

System ranking is quite different for NRE consumption compared with gross GHG emissions (Table 2). Three farms (Irel, $3 \times 2$, and $O F$ ) get the highest NRE consumption (between 47.6 and $50.9 \mathrm{MJ} \mathrm{kg} \mathrm{carc.}^{-1}$ ), as they use a high amount of mineral fertilisation (Irel) and sometimes concentrate feed that represent up to $30 \%$ of total NRE $(3 \times 2)$. In the $O F$ farm, input levels 
are lower, but NRE consumption per $\mathrm{kg}$ of carcass is high because of a lower ewe productivity and meat production per ewe, and a high quantity of forage stocks required per ewe. System Graz has a low level at $31.4 \mathrm{MJ} \mathrm{kg}^{-1}$ and $D T$ system has the lowest, at $22.7 \mathrm{MJ} \mathrm{kg}^{-1}$ carcass with its very limited inputs and very little mechanisation (no stocks for winter). In this farm, fuel however accounts for $62 \%$ of total NRE (for flock surveillance and animal transportation). In the Irish farm fuel accounts for $10 \%$ of NRE only, while energy for mineral fertilisation accounts for $38 \%$.

\subsubsection{Comparisons of GHG emissions and energy consumption to French networks}

Average GHG emissions calculated from the database of 1180 farm years (Benoit and Laignel 2011) in the Inra network is $31.6 \mathrm{~kg} \mathrm{Eq} \mathrm{CO} \mathrm{kg}^{-1}$ carcass (Benoit and Dakpo 2012). All five farms are below this level, even $D T$ at $28.6 \mathrm{~kg} \mathrm{Eq} \mathrm{CO}_{2}$ $\mathrm{kg}^{-1}(-10 \%)$ in spite of its low ewe productivity. Graz, Irel, $3 \times 2$, and $O F$ are $42 \%, 31 \%, 29 \%$, and $21 \%$ lower, respectively, thanks to good ewe productivity and high lamb weight for Graz and Irel that are "diluting" emissions of enteric $\mathrm{CH}_{4}$.

Regarding energy consumption, Bellet et al. (2016) showed that conventional farming systems based on grass utilisation or pastoral systems use an average 27.1 and $30.1 \mathrm{MJ} k g$ live ani$\mathrm{mal}^{-1}$, respectively (without indirect MJ of equipment), which corresponds to $60-70 \mathrm{MJ} / \mathrm{kg}$ carcass. Non-renewable energy consumption is around half this average in Graz and DT and $20 \%$ lower in $3 \times 2, O F$, and Irel systems.

\subsection{Synthesis of overall performance}

Overall, this analysis shows how the different systems compare in the four dimensions of performance. The three farms (DT, Graz, Irel) maximising the use of local resources with a long grazing season and low feed stocks provide (i) the best economic performance in terms of added value $(31,900$, $31,700,40,500 € \mathrm{~W}^{-1}$ (in the same economic situation) $v s$ 19,800 and $22,500 € \mathrm{~W}^{-1}$ for $3 \times 2$ and $O F$, respectively) and (ii) the lowest feed/food competition $(158 \%, 125 \%$, and $\infty$ compared to $33 \%$ and $51 \%$ for $3 \times 2$ and $O F$, respectively). DT and Graz also show the lowest NRE consumption (22.7 and $31.4 \mathrm{MJ} \mathrm{kg} \mathrm{carc}{ }^{-1}$, respectively) compared to Irel, $3 \times 2$, and $O F$ (47.6 to $50.9 \mathrm{MJ} \mathrm{kg} \mathrm{carc}{ }^{-1}$ ). However, these high performing system production systems require (i) lambs to be fattened during the grass growing season and thus to be sold mainly between July and November and (ii) to have a specific market for old male lambs in the case of $D T$. In situations of very low $(D T)$ or lenient (Graz) stocking rates and levels of pasture intensification, we observe very good environmental results at farm level. In the Irish farm, the high price of land requires to enhance lamb production per ha which utilises high levels of $\mathrm{N}$ mineral fertilisation and increases
GHG emissions $\left(\mathrm{N}_{2} \mathrm{O}\right)$ as well as indirect energy consumption, thus leading to poorer environmental performance. In the less productive farms, high $\mathrm{CH}_{4}$ emissions per $\mathrm{kg}$ of carcass is mitigated by high carbon sequestration per $\mathrm{kg}$ carcass in pastures $(O F$ and $D T)$. In the case of very low ewe productivity as for $D T$, the need to achieve high economic and environmental performance is to be fully self-sufficient for feed and to use nearly no inputs. The two farms that adopted counter season lambing require more inputs (especially concentrate feeds) with three direct consequences: lower added value, poorer environmental performance in term of energy consumption (concentrate feeds and equipment for stock), and high levels of feed-food competition (especially, cereals from concentrate feeds and pulses). Conversely, they better match the meat industry demand for a higher and more regular lamb meat supply ( $3 \times 2)$ and quality sign lambs $(O F)$ throughout the year.

\subsection{Optimisation of local resources and market constraints. What convergence and trade-offs?}

Concentrate feed gives a great flexibility to farmers to modify reproduction periods and to fatten lambs easily in all contexts while increasing meat production in particular when land area is limited. It also secures production when grassland-based systems face feed shortages for example as the consequence of summer droughts, and facilitate the supply of lamb carcasses of stable quality (regular growing, homogeneity of batches). These systems are affected little by fluctuations in grass quality and quantity and offer opportunities to maximise animal genetic merit and high prices for lambs (see $3 \times 2$ ). Using concentrates may also have some sanitary benefits, in particular to limit parasitism by increasing the sheep resistance depending on diet offered (Coop and Kyriazakis 1999). One of the main negative aspects is the impact on farm profitability due to the high and fluctuating cost of concentrate feeds, while pastures and rangelands represent a cheap and potentially high-nutritive resource. The limitation of concentrate use at farm scale implies that ewes have the ability to mobilise and recover body reserves. Although often showing low lamb conformation, rustic breeds can offer such ability to valorise various types of forage, in particular in harsh grazing conditions. They however often have to be crossbred so as to increase lamb conformation, which complicates farm management. Rustic breeds also display advantages for reproduction, with good fertility for spring mating, therefore avoiding hormonal treatments that concern the large majority of French grass-based systems using well-conformed breeds.

Choice of breeds is central in farmers' strategies and success, with various capacities and production levels, and sometimes low adaptation to industry requirements. As summarised in Table 1, this choice differed across the five farms and breed appeared as a key lever to adapt to contrasting opportunities and constraints. 


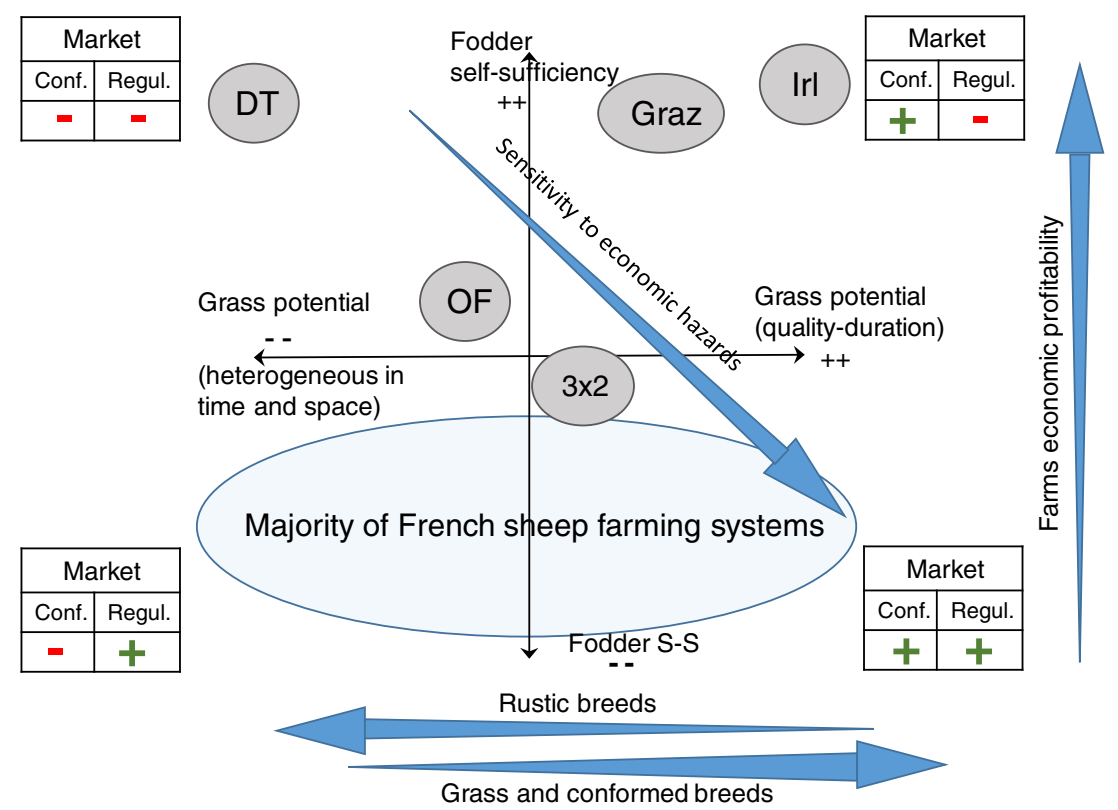

Fig. 3 Schematic representation to position sheep farming systems on both grass potential and grass level of utilisation (fodder selfsufficiency), and consequences on market adequacy: in the graph corners, we estimate the level of adaptation to market demand in term of lamb conformation ('Conf.') and selling regularity along the year ('Regul' as regular selling). Horizontal blue arrows show the type of breeds used in low or high grass potential situations, in relation with

Figure 3 summarises the main findings of our work. It outlines the strategies of farmers that more or less optimise the use of fodder resources under contrasted environmental conditions, while aiming to meet the expectations of the lamb meat industry. The $X$-axis accounts for the gradient of grass potential, while the $Y$-axis accounts for farm fodder self-sufficiency. The majority of the sheep farms in our database (Fig. 2) are in the lower part of the graph, with fodder selfsufficiency usually between 70 and $85 \%$. These farms usually plan part of their lambing in counter season, providing lambs in winter, with good conformation in lowland conditions. Farm $3 \times 2$ is close to the bottom-right quarter of the graph, providing the best answer to the sheep industry demand among the five farms. Farms Graz and Irel provide good quality lambs (conformation) but only between July and November. $D T$ provides lambs only during 4 months, with quality not matching the global sheep industry standards, but meeting local demand (old males lambs), while female lambs are sold before fattening. $O F$ is in an intermediate position.

In our study, even with optimised flock management and in a rather good economic situation (price of the meat), the profitability remains lower in concentrate-based than in grass-based farming systems, and the added-value indicator confirms the lower optimisation of local resources. One can also conclude that the lamb price is too low in counter season production systems considering the extra costs of lamb production. lamb conformation. Diagonal arrow points out the sensitivity to economic hazards, in relation with levels of animal intensification and input use, and vertical arrow indicates that best farm profitability is on top part. DT for Dual Transhumant system, $O F$ for Organic Farming, $3 \times 2$ for accelerated reproduction system, Graz for Grazing system, Irel for the Irish system

Moreover, energy consumption, feed/food competition, and sometimes net GHG emissions are poor in very productive concentrate-based farming systems.

Interestingly, this analysis illustrates that reaching high economic performance is de-correlated with the achievement of the different market standards, especially seasonality. The farming systems that reach the highest levels of added value are those that do not respect market seasonality, which illustrates an advantage to adapt for climatic variability and agronomic potential before to meat industry demand. So, if they perform so well, what does limit the scaling-up of such agroecological systems? These grass-based sheep farming systems indeed require both specific skills and marketing adequacy. Some specific markets can be an opportunity, such as the Muslim market for male lambs in southeast France or short chains marketing channels meeting alternative consumer expectations (referring to the "naturality" of products). For farmers who cannot access alternative markets, this antagonism between farm strategies to reduce inputs (in particular concentrate feeds) and demands from the lamb meat industry are a major issue. In order to meet the requirement of lamb supply to the sheep industry, a larger-scale strategy would be to explore farming systems complementarities both within and between livestock production areas. Autumn lambing farming systems with adapted breeds (natural mating in spring but often low conformation) can be considered as complementary 
to the end of winter lambing farming systems such as Graz or Irel, with well-conformed breeds (Benoit and Laignel 2011). However, this raises the question of homogeneous lamb characteristics (age, conformation, taste, etc.) (Prache 2014) and requires adaptation from the sheep industry to deal with lamb carcass variability. There is indeed some evidence that feeding lambs on grass-based diets affect carcass quality and meat nutritional quality, with either positive consequences (desirable fatty acid or antioxydant compounds) (Aurousseau et al. 2007) or negative ones on meat flavour (Prache 2014).

\section{Conclusion}

The economic performance of the five farms studied are far above the sheep farm average. Each type develops a specific strategy in regard to environmental conditions for an overall high efficiency of concentrate feed utilisation.

The analysis of these five very efficient farming systems points out the antagonism between the maximisation of onfarm forage utilisation and farm profitability on the one hand, and lamb's ideotype required by the sheep-meat industry on the other hand. It shows that farmers who manage to reach high profitability are those who give a greater importance to adapting their system to the environment than to the demands of the meat industry. Such grass-based and efficient farming systems are rather scarce in France. They require high technicity, observation and adaptation capability from farmers, as illustrated by $D T$ farm that provide high environmental and economic performances with very low inputs.

It would be worthwhile to extend this analysis to a wider range of regulating and cultural services provided by sheep grassland-based farming systems. The bundle of services framework proposed by Ryschawy et al. (2019) allows accounting for a wider range of sustainability drivers (labour and employment, social and cultural factors, biodiversity) beyond the economic and environmental performance indicators that were calculated in this article. It thus provides a wider basis for comparing sheep-meat production systems.

\section{Compliance with ethical standards}

Conflict of interest The authors declare that they have no conflict of interest.

\section{References}

Aurousseau B, Bauchart D, Faure X, Galot AL, Prache S, Micol D, Priolo A (2007) Indoor fattening of lambs raised on pasture. Part 1: influence of stall finishing duration on lipid classes and fatty acids in the longissimus thoracis muscle. Meat Sci 76(2):241-252. https://doi. org/10.1016/j.meatsci.2006.11.005
Bellet V, Ferrand M (2014) Leviers de réduction des coûts de production en élevage ovin viande. Renc Rech Ruminants 21:187-190

Bellet V, Experton C, Gac A, Laignel G, Morin E (2016) Les systèmes ovins biologiques sont-ils plus durables que les conventionnels ? Renc Rech Ruminants:243-246

Benoit M (1998) A tool for simulation of sheep flock functioning, with it's economic results: a help for adaptation to new contexts. INRA Prod Anim 11(3):199-209

Benoit M, Dakpo H (2012) Greenhouse gas emissions on french meat sheep farms: analysis over the period 1987-2010. Emissions of Gas and Dust from Livestock, Edits. Hassouna M., Guigand N. Proceedings Emili 2012 congress, pp 384-387

Benoit M, Laignel G (2006) Methods for processing technical and economic data on suckling sheep. The case of plain and mountain areas in France. Options Mediterraneennes. Serie A, Seminaires Mediterraneens (70):57-65 http://om.ciheam.org/om/pdf/a70/ 00800006.pdf

Benoit M, Laignel G (2011) Long term analysis of meat sheep farming systems in France. Which dynamics of evolution and which factors can explain the economical performance? Inra Productions Animales 24(3):211-220

Benoit M, Laignel G (2014) Sheep-for-meat farming systems in French semi-upland area. Adapting to new context: increased concentrates and energy prices, and new agricultural policy. Int J Sustain Dev 17(1):35-48. https://doi.org/10.1504/ijsd.2014.058435

Coop RL, Kyriazakis I (1999) Nutrition-parasite interaction. Vet Parasitol 87: 187-204

Dollé J, Faverdin P, Agabriel J, Sauvant D, Klumpp K (2013) Contribution de l'élevage bovin aux émissions de GES et au stockage de carbone selon les systèmes de production. Fourrages 2015:181-191

Dumont B, Groot JCJ, Tichit M (2018) Review: make ruminants green again - how can sustainable intensification and agroecology converge for a better future? Animal 12(S2):s210-s219. https://doi. org/10.1017/S1751731118001350

Dumont B, Ryschawy J, Duru M, Benoit M, Chatellier V, Delaby L, Donnars C, Dupraz P, Lemauviel-Lavenant S, Méda B, Vollet D, Sabatier R (2019) Review: associations among goods, impacts and ecosystem services provided by livestock farming. Animal 13(8): in press. https://doi.org/10.1017/s1751731118002586

Earle E, Boland TM, McHugh N, Creighton P (2017) Measures of lamb production efficiency in a temperate grass-based system differing in ewe prolificacy potential and stocking rate. J.ANim. Sci 95(8): 3504-3512. https://doi.org/10.2527/jas2017.1427

Ertl P, Klocker H, Hörtenhuber S, Knaus W, Zollitsch W (2015) The net contribution of dairy production to human food supply: the case of Austrian dairy farms. Agric Syst 137:119-125. https://doi.org/10. 1016/j.agsy.2015.04.004

European Parliament (2008) The future of sheep and goat sector in Europe. Policy Department. Structural and Cohesion Policies. IP/ B/AGRI/IC/2007_043: 109p

Gac A, Cariolle M, Deltour L, Dollé JB, Espagnol S, Flénet F et al (2011) GES'TIM - des apports pour l'évaluation environnementale des activités agricoles. Innovations Agronomiques 17:83-94

Lasseur J (2008) What means adapting to wolf reappearance for sheep farmers in French Southern Alps? Book of abstracts of the 59th annual meeting of the European Association for Animal Production https://prodinra.inra.fr/ft?id $=\{1 \mathrm{D} 097 \mathrm{~F} 8 \mathrm{C}-9 \mathrm{D} 8 \mathrm{~A}-40 \mathrm{FD}$ A1D0-87ACD256FB50 Accessed July 2018: 7p

Mottet A, de Haan C, Falcucci A, Tempio G, Opio C, Gerber P (2017) Livestock: on our plates or eating at our table? A new analysis of the feed/food debate. Glob Food Sec 14:1-8. https://doi.org/10.1016/j. gfs.2017.01.001

O'Rourke E, Charbonneau M, Poinsot Y (2016) High nature value mountain farming systems in Europe: case studies from the Atlantic 
Pyrenees, France and the Kerry Uplands, Ireland. J Rural Stud 46: 47-59. https://doi.org/10.1016/j.jrurstud.2016.05.010

OECD (2015) OECD-FAO Agricultural Outlook 2015. Editions OECD, Paris $159 \mathrm{p}$

Prache S (2014) Advances, issues and challenges in organic lamb meat quality. In: S Bellon \& S Penvern (eds) Organic farming, prototype for sustainable agricultures. Chapter 17: 313-324

Ripoll-Bosch R, Joy M, Bernues A (2014) Role of self-sufficiency, productivity and diversification on the economic sustainability of farming systems with autochthonous sheep breeds in less favoured areas in Southern Europe. Animal 8(8):1229-1237. https://doi.org/10. $1017 / \mathrm{S} 1751731113000529$

Rossi R (2017) The sheep and goat sector in the EU Main features, challenges and prospects. European Parliamentary Research Service: $8 \mathrm{p}$

Royer JY (1988) Le journal de Noé de Barras, un entrepreneux de transhumance au XVe siécle. Les Alpes de lumière 98: 75p

Ryschawy J, Dumont B, Therond O, Donnars C, Hendrickson J, Benoit M, Duru M (2019) Review: an integrated graphical tool for analysing impacts and services provided by livestock farming. Animal 13(8): in press. https://doi.org/10.1017/S1751731119000351
Vermorel M, Jouany JP, Eugène M, Sauvant D, Noblet J, Dourmad JY (2008) Evaluation quantitative des émissions de méthane entérique par les animaux d'élevage en 2007 en France. INRA Prod Anim 21(5):403-418

Vigan A, Lasseur J, Benoit M, Mouillot F, Eugène M, Mansard L, Vigne M, Lecomte P, Dutilly C (2017) Evaluating livestock mobility as a strategy for climate change mitigation: combining models to address the specificities of pastoral systems. Agric Ecosyst Environ 242:89 101. https://doi.org/10.1016/j.agee.2017.03.020

Watson CA, Atkinson D (1999) Using nitrogen budgets to indicate nitrogen use efficiency and losses from whole farm systems: a comparison of three methodological approaches. Nutr Cycl Agroecosyst 53: 259-267

Wilkinson JM (2011) Re-defining efficiency of feed use by livestock. Animal 5(7):1014-1022. https://doi.org/10.1017/ S175173111100005X

Publisher's note Springer Nature remains neutral with regard to jurisdictional claims in published maps and institutional affiliations. 